\title{
Determination of Trace Metals with Newly Synthesized Coniine Dithiocarbamate by Atomic Absorption Spectroscopy
}

\author{
K. SUVARDHAN, K. SURESH KUMAR, K.M. REDDY \\ M. V. JYOTHI and P. CHIRANJEEVI* \\ *Environmental Monitoring Laboratories, \\ Department of Chemistry, S.V.University, Tirupati-517 502, A.P. India. \\ chiranjeevi_sai@yahoo.co.in
}

Received 26 February 2004; Accepted 10 March 2004

\begin{abstract}
A procedure is developed for the determination of $\mathrm{Cd}, \mathrm{Cu}, \mathrm{Mo}, \mathrm{Pb}, \mathrm{Te}$ and $\mathrm{Ni}$ in natural and spiked water by Atomic Absorption Spectroscopy (AAS) after preconcentration on a coniine dithiocarbamate supported by polyurethane. The sorbed elements are subsequently eluted with $5 \mathrm{~mol} \mathrm{~L}^{-1} \mathrm{HNO}_{3}$ and the acid eluates are analysed by AAS. A $20 \mathrm{~mL}$ syringe served as a chromatographic preconcentration column. The sorption recoveries of elements were higher in the order of $99 \%$. The method is also applied successfully for the determination of $\mathrm{Cu}$, $\mathrm{Cd}, \mathrm{Mo}, \mathrm{Pb}, \mathrm{Te}$ and $\mathrm{Ni}$ in natural and spiked water samples.
\end{abstract}

Keywords: Trace elements, Coniine dithiocarbamate, A A S.

\section{Introduction}

Environmental pollution monitoring requires determination of toxic heavy elements in trace levels. The Atomic Absorption Spectrometry (AAS) technique, which offers fast multielemental analysis, suffers from a poor sensitivity in the determination of heavy elements in environmental samples like natural water and other real samples. This draw back can be overcome by a combination of a suitable preconcentration technique with subsequent AAS determination. Preconcentration methods that can be used for water samples are solvent extraction, coprecipitation, resin chelation and various chromatographic technique. ${ }^{1-8}$ These preconcentration methods provides low detection limits and also helps to avoid matrix interferences in the analysis of real samples. Extraction of the dithiocarbamate complexes of metals in the isobutyl methyl ketone (1 BMK) and subsequent determination has been widely applied in the determination of metals in natural water. However, this simple solvent extraction concentration procedure can not be combined with $\mathrm{AAS}^{9-10}$. In view of this, several workers tried a column solid phase extraction method for the determination of metals by AAS 
Column solid-phase extraction has some advantages over liquid-liquid extraction. The possibility of combination with ICP-AES as well as with AAS allows preconcentration from a larger sample volume, establishing higher concentration factors, simple storage and transportation of the pretreated samples. ${ }^{11}$ Here authors report a method for preconcentration of trace elements, viz., $\mathrm{Cd}, \mathrm{Cu}, \mathrm{Mo}, \mathrm{Pb}, \mathrm{Te}$ and $\mathrm{Ni}$ on a polyurethane foam support impregnated with coniine dithiocarbamate. The sorbed elements were sequently eluted with $5 \mathrm{~mol} \mathrm{l}^{-1} \mathrm{HNO}_{3}$. The acid eluates were further analysed by AAS.

\section{Experimental}

\section{Materials and Methods}

All reagents and chemicals used were of Analytical Reagent grade. Deionized doubly distilled water was used through out the experiments. A multielement standard solution $(0.1$ $\mathrm{mg} \mathrm{mL}^{-1}$ ) was prepared by appropriate dilution of AAS standards (Merck Germany) of Cd, $\mathrm{Cu}, \mathrm{Mo}, \mathrm{Pb}, \mathrm{Te}$ and Ni. Working standards of $\left(0.1,0.2,0.5,0.8\right.$ and $\left.1.0 \mathrm{ng} \mathrm{mL} \mathrm{mL}^{-1}\right)$ were prepared by appropriate dilution of multielement standard with deionized distilled water. Nitric acid was used with out additional purification.

\section{Synthesis of sodium salt of coniine dithio carbamate}

Sodium salt of coniine dithiocarbamate was prepared by slowly adding $80 \mathrm{~g}$ of carbondi-sulphide to a solution of coniine $(85 \mathrm{~g})$ in $25 \mathrm{~mL}$ of water at $5^{\circ} \mathrm{C}$ with constant stirring, followed by $40 \mathrm{~g}$ of sodium hydroxide dissolved in $20 \mathrm{~mL}$ of water as shown in Figure 1. The product was warmed to room temperature, washed repeatedly two or three times with purified acetone. The reaction product was purified by recrystalization in acetone. The compound thus produced has a melting point of $303-308^{\circ} \mathrm{C}$ at $740 \mathrm{~mm}$ pressure.

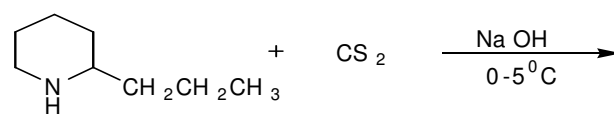

Coniine

Carbondisulphide

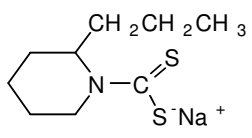

Coniine dithiocarbamate

Figure 1. Synthesis of conline dithiocarbam ate reagent.

Acetate buffer was prepared by dissolving $8.2 \mathrm{~g}$ sodium acetate in $800 \mathrm{~mL}$ water. It was adjusted by $\mathrm{pH} 6.0$ with high purity glacial acetic acid. It was stored in a clean polyethylene bottle. 20 plus varian atomic absorption spectrometer with a hallow cathode lamp, using an $\mathrm{N}_{2} \mathrm{O}$ - acetylene flame for determination of traces of heavy metals. The AAS determination of all other cations was performed under the recommended conditions for each metal. The $\mathrm{pH}$ was determined with a model 632 Metrohm $\mathrm{pH}$ meter with a combined glass-calomel electrode.

\section{Column preparation}

Medical Syringes $(20 \mathrm{~mL})$ were used as columns. The support was prepared from soft polyurethane foam in the following manner. $1 \mathrm{~cm}$ thick segments with diameter of $2.5 \mathrm{~cm}$ were cut. The segments were soaked in $5 \mathrm{~mol} \mathrm{l}^{-1}$ nitric acid for $15 \mathrm{~h}$, washed in deionized doubly distilled water and dried prior to use. The syringes were then filled with the air-dried segments. The column consists 7-8 separate segments. Then $3.0 \mathrm{~g}$ of solid coniine dithiocarbamate was introduced between the segments. This amount of the complex forming agent was necessary to retain the $100 \mu \mathrm{g}$ of each element in $200 \mathrm{~mL}$ sample. Prior to passing the next $200 \mathrm{~mL}$ sample, an additional $3.0 \mathrm{~g}$ of solid coniine dithiocarbamate was introduced in to the column by replacing the polyurethane foam segments with a new set of segments. 


\section{Procedure}

The $20 \mathrm{~mL}$ of standard solution containing elements $\mathrm{Cd}, \mathrm{Cu}, \mathrm{Mo}, \mathrm{Pb}, \mathrm{Te}$ and $\mathrm{Ni}$ was taken and the $\mathrm{pH}$ was adjusted to $6 \pm 0.2$ with ammonia solution $(1: 1)$ or $\mathrm{HCl}(1+1)$ and $2 \mathrm{~mL}$ of acetate buffer. The solution of the elements was sucked in the column and allowed to contact for $30 \mathrm{~min}$, then the liquid phase was allowed to drain by removing the piston. Elution was performed by adding $10 \mathrm{~mL}$ of $5 \mathrm{~mol} \mathrm{l}^{-1} \mathrm{HNO}_{3}$ to the column by removing the piston. This solution was then allowed to pass through the column. The acid eluent was collected in the polyethylene bottle. Then $2 \mathrm{~mL}$ of double distilled water was added and the eluent was collected. Both the eluents were combined and nebulized in to $\mathrm{N}_{2} \mathrm{O}$ - acetylene flame of AAS.

\section{Procedure for the determination of trace metals in spiked water}

The extraction efficiency was studied by using spiked water samples for the recovery of trace metals. Deionised doubly distilled water were spiked with known amounts of multi elemental standards( $15 \mathrm{ng} / \mathrm{l}, 30 \mathrm{ng} / \mathrm{l}$, and $60 \mathrm{ng} / \mathrm{l}$ ) and allowed to stand for overnight. The concentration of metals in spiked waters were deterrmined as described in general procedure.

\section{Preconcentration of trace elements in natural water samples}

Water sample $(200 \mathrm{~mL})$ filtered through a $0.45 \mu \mathrm{m}$ membrane filter was taken and $\mathrm{pH}$ was adjusted to $6 \pm 0.2$ with $\mathrm{HCl}(1+1)$ or dilute ammonia solution $(1: 1)$ and $2 \mathrm{~mL}$ of acetate buffer, and passed through the chromatographic columns at a flow rate of $2 \mathrm{~mL} \mathrm{~min}^{-1}$. The column was then washed with $5 \mathrm{~mL}$ of doubly deionized distilled water. The sorbed metal ions were eluted with $10 \mathrm{~mL}$ of $5 \mathrm{~mol} \mathrm{l}^{-1} \mathrm{HNO}_{3}$, after which $2 \mathrm{~mL}$ of doubly distilled water was added through the sorbent and determined as described above.

\section{Results and Discussion}

The effect of $\mathrm{pH}$ on the preconcentration of metals on polyurethane foam loaded with coniine dithio-carbamate was studied by determination of $20 \mu \mathrm{g}$ of individual elements in the $\mathrm{pH}$ range of 2.0-8.0 and by introducing $1.0 \mathrm{~g}$ of coniine dithiocarbamate between the polyurethane foam segments. The elution was performed with $5 \mathrm{~mol} \mathrm{l}^{-1} \mathrm{HNO}_{3}$. The data corresponding to each element was shown in Figure 2.

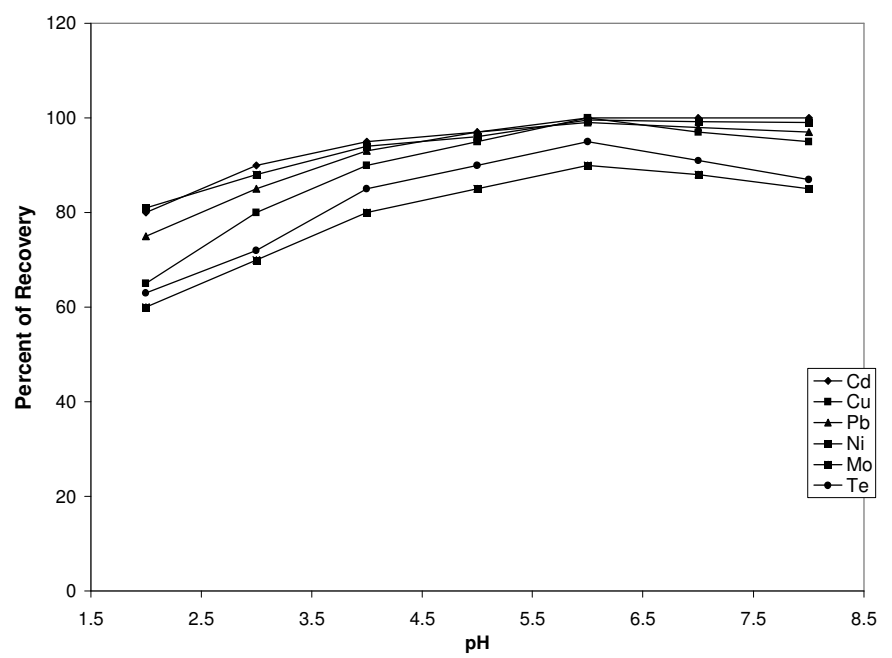

Figure 2. Effect of $\mathrm{pH}$ on the Complexation of Metal with Coniinedithio Carbamate 
At pH 6.0 maximum recovery was obtained for all the elements. So the $\mathrm{pH} 6.0 \pm 0.2$ has been selected for the determination of metals in water.The optimum amount of the chelate forming reagent ensuring quantitative sorption of the studied elements was established. It was observed that the optimum amount of coniine dithiocarbamate depend on the volume of sample passing through the column. Experiments were carried out with solid coniine dithiocarbamate $(1.0-10 \mathrm{~g})$ spread between the polyurethane foam segments. It was established that $3.0 \mathrm{~g}$ of solid coniine dithiocarbamate was enough to provide quantitative retention of $100 \mu \mathrm{g}$ of each element in a $200 \mathrm{~mL}$ water samples at $\mathrm{pH} 6.0 \pm 0.2$ and subsequent elution was carried out with $5 \mathrm{~mol} \mathrm{l}^{-1} \mathrm{HNO}_{3}$

The choice of the eluent was a difficult problem because of the limitation of the AAS to tolerate organic solvents. In addition, the eluent should not destroy the polyurethane foam. Hence for the simultaneous determination of the preconcentrated elements by AAS, the elution was performed with 2.5-6.0 mol l-1 $\mathrm{HNO}_{3}$. The elution is dependent on the concentration of $\mathrm{HNO}_{3}$ as shown in Figure 3. Quantitative multielement elution was achieved for $5 \mathrm{~mol} \mathrm{l}^{-1} \mathrm{HNO}_{3}$. Hence $5 \mathrm{~mL}$ of $5 \mathrm{~mol} \mathrm{l}^{-1} \mathrm{HNO} 3$ was chosen as the optimum eluent for the multielement determination. The recoveries were about $99 \%$. The precision of the procedure was investigated by determining the elements in spiked water samples. The detection limits of each elements was expressed as the amount of analyte in $\mu \mathrm{g} / \mathrm{mL}$ giving a signal to noise ratio of 3 .

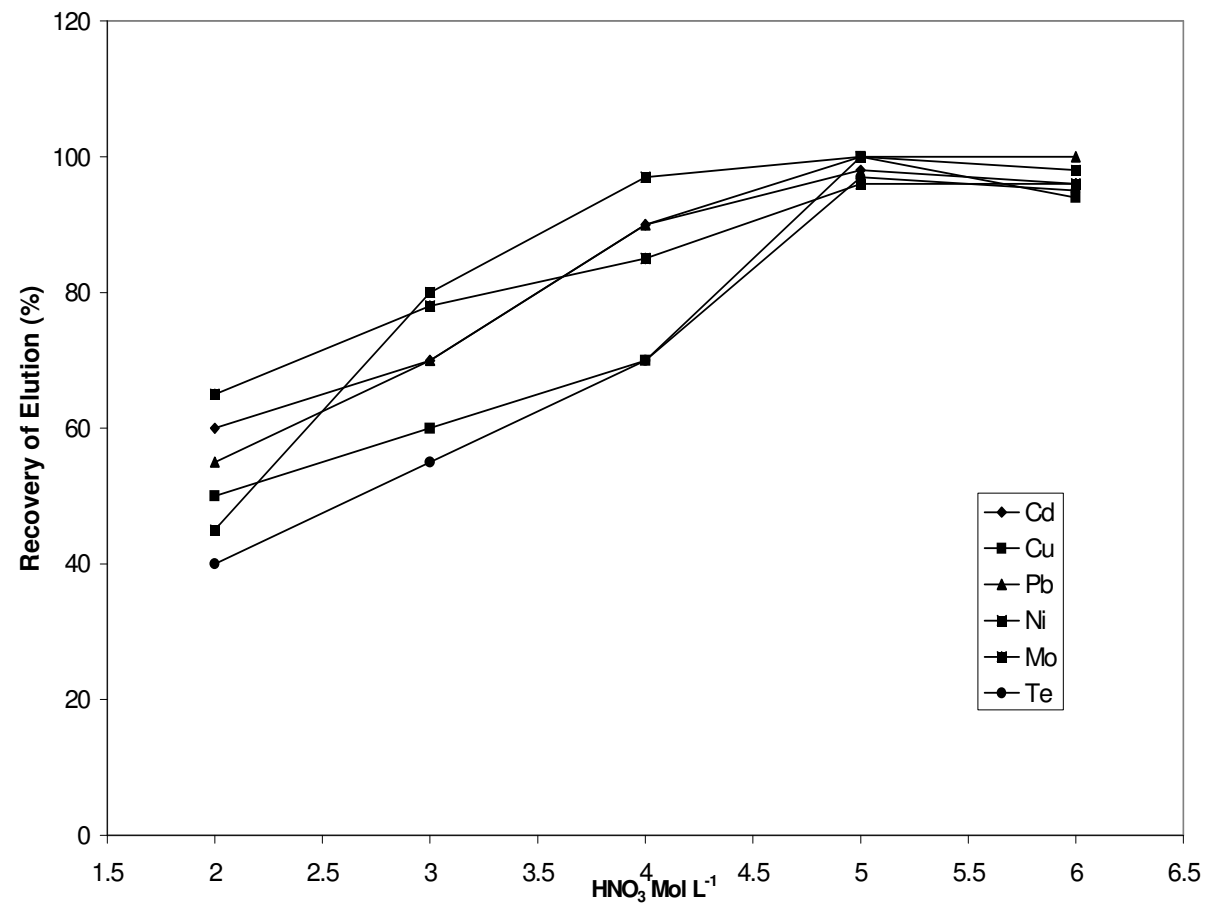

Figure 3. Effect of $\mathrm{HNO}_{3}$ Concentration on Elution of Metals

The detection limit and per cent of recovery for each element in spiked water samples are given in Figure 4 and Table 1 respectively. The results show sufficiently high recoveries (99\%) for the $\mathrm{Cd}, \mathrm{Cu}, \mathrm{Mo}, \mathrm{Pb}, \mathrm{Te}$ and $\mathrm{Ni}$ with a RSD of 2.75 to $3.32 \%$ and determination of trace elements in natural water samples around Tirupati town are shown in Table 2. 
Table 1. Recovery of trace elements from spiked water samples. After preconcentration on polyurethane foam loaded with coniine dithiocarbamate

\begin{tabular}{|c|c|c|c|c|c|c|c|c|c|}
\hline \multirow[t]{2}{*}{ Elements } & \multicolumn{3}{|c|}{$\begin{array}{l}\text { Concentration of each } \\
\text { Element Added, } 15 \mathrm{ng} / \mathrm{l}\end{array}$} & \multicolumn{3}{|c|}{$\begin{array}{l}\text { Concentration of each } \\
\text { Element Added,30 ng/l }\end{array}$} & \multicolumn{3}{|c|}{$\begin{array}{l}\text { Concentration of each } \\
\text { Element Added, } 60 \mathrm{ng} / 1\end{array}$} \\
\hline & $\begin{array}{l}\text { Found, } \\
\text { ng/l }\end{array}$ & $\begin{array}{c}\text { Recovery }{ }^{\mathrm{a},} \\
\%\end{array}$ & $\begin{array}{c}\mathrm{RSD}^{\mathrm{a}}, \\
\%\end{array}$ & $\begin{array}{l}\text { Found, } \\
\text { ng/l }\end{array}$ & $\begin{array}{c}\text { Recovery }{ }^{\mathrm{a}}, \\
\%\end{array}$ & $\begin{array}{c}\mathrm{RSD}^{\mathrm{a}} \\
\%\end{array}$ & $\begin{array}{l}\text { Found, } \\
\text { ng/l }\end{array}$ & $\begin{array}{c}\text { Recovery }^{\mathrm{a}}, \\
\%\end{array}$ & $\begin{array}{c}\mathrm{RSD}^{\mathrm{a}}, \\
\%\end{array}$ \\
\hline $\mathrm{Cd}$ & 14.68 & 97.80 & 3.31 & 29.38 & 97.93 & 3.32 & 58.50 & 97.5 & 3.29 \\
\hline $\mathrm{Cu}$ & & & & & & & & 98.0 & \\
\hline Мo & 14.70 & 98.0 & 3.19 & 29.45 & 98.16 & 3.20 & 59.0 & 97.8 & 3.19 \\
\hline $\mathrm{Pb}$ & 14.62 & 97.40 & 2.92 & 29.30 & 97.60 & 2.75 & 58.70 & 98.91 & 2.93 \\
\hline $\mathrm{Te}$ & 14.80 & 98.60 & 3.19 & 29.65 & 98.83 & 3.21 & 59.35 & 98.60 & 3.20 \\
\hline $\mathrm{Ni}$ & 14.73 & 98.20 & 3.05 & 29.50 & 98.30 & 3.08 & 59.25 & 99.50 & 3.10 \\
\hline & 14.85 & 99.0 & 2.84 & 29.75 & 99.16 & 2.89 & 59.70 & & 2.95 \\
\hline
\end{tabular}

a \% Recovery and \% RSD for four determination

Table 2. Determination of trace elements in natural water samples around Tirupati town

\begin{tabular}{|c|c|c|c|c|c|c|c|c|c|c|c|c|}
\hline \multirow[b]{2}{*}{$\begin{array}{l}\text { Samples } \\
\text { Collected }\end{array}$} & \multicolumn{2}{|c|}{$\mathrm{Cd}$} & & $\mathrm{Cu}$ & \multicolumn{2}{|c|}{ Mo } & \multicolumn{2}{|c|}{$\mathrm{Pb}$} & \multicolumn{2}{|c|}{$\mathrm{Te}$} & \multicolumn{2}{|c|}{$\mathrm{Ni}$} \\
\hline & 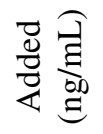 & 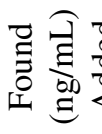 & & 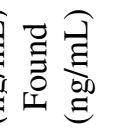 & 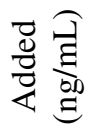 & 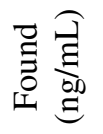 & 总 & 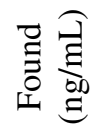 & 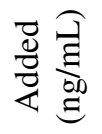 & 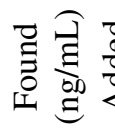 & 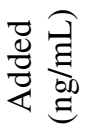 & 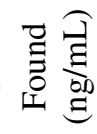 \\
\hline $\begin{array}{l}\text { Kalyanidam } \\
\text { reservoir }\end{array}$ & - & $\begin{array}{l}19.5 \\
\pm 0.2\end{array}$ & - & $\begin{array}{l}17.3 \\
\pm 0.4\end{array}$ & - & $\begin{array}{l}16.2 \\
\pm 0.2\end{array}$ & - & $\begin{array}{l}18.6 \\
\pm 0.3\end{array}$ & 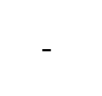 & $\begin{array}{l}15.5 \\
\pm 0.4\end{array}$ & - & $\begin{array}{l}19.8 \\
\pm 0.3\end{array}$ \\
\hline $\begin{array}{l}\text { Swarnamukhi } \\
\text { river belt }\end{array}$ & - & $\begin{array}{l}20.1 \\
\pm 0.6\end{array}$ & - & $\begin{array}{l}18.5 \\
\pm 0.5\end{array}$ & - & $\begin{array}{l}10.5 \\
\pm 0.3\end{array}$ & - & $\begin{array}{l}20.0 \\
\pm 0.5\end{array}$ & - & $\begin{array}{l}16.6 \\
\pm 0.2\end{array}$ & - & $\begin{array}{l}21.2 \\
\pm 0.4\end{array}$ \\
\hline $\begin{array}{l}\text { Amararaja } \\
\text { Batteries } \\
\text { industry }\end{array}$ & - & $\begin{array}{l}24.4 \\
\pm 0.2\end{array}$ & - & $\begin{array}{l}22.5 \\
\pm 0.4\end{array}$ & - & $\begin{array}{l}18.2 \\
\pm 0.2\end{array}$ & - & $\begin{array}{l}25.0 \\
\pm 0.6\end{array}$ & - & $\begin{array}{l}17.3 \\
\pm 0.3\end{array}$ & - & $\begin{array}{l}24.6 \\
\pm 0.5\end{array}$ \\
\hline $\begin{array}{c}\text { Srikalahastri } \\
\text { area }\end{array}$ & - & $\begin{array}{l}19.7 \\
\pm 0.1\end{array}$ & - & $\begin{array}{l}18.8 \\
\pm 0.2\end{array}$ & - & $\begin{array}{l}17.5 \\
\pm 0.2\end{array}$ & - & $\begin{array}{l}19.2 \\
\pm 0.3\end{array}$ & - & $\begin{array}{l}16.8 \\
\pm 0.2\end{array}$ & - & $\begin{array}{l}20.6 \\
\pm 0.1\end{array}$ \\
\hline $\begin{array}{c}\text { Municipal } \\
\text { waste water }\end{array}$ & - & $\begin{array}{l}21.6 \\
\pm 0.2\end{array}$ & - & $\begin{array}{l}21.8 \\
\pm 0.3\end{array}$ & - & $\begin{array}{l}17.0 \\
\pm 0.2\end{array}$ & - & $\begin{array}{l}23.0 \\
\pm 0.2\end{array}$ & - & $\begin{array}{l}16.1 \\
\pm 0.4\end{array}$ & - & $\begin{array}{l}24.1 \\
\pm 0.2\end{array}$ \\
\hline
\end{tabular}




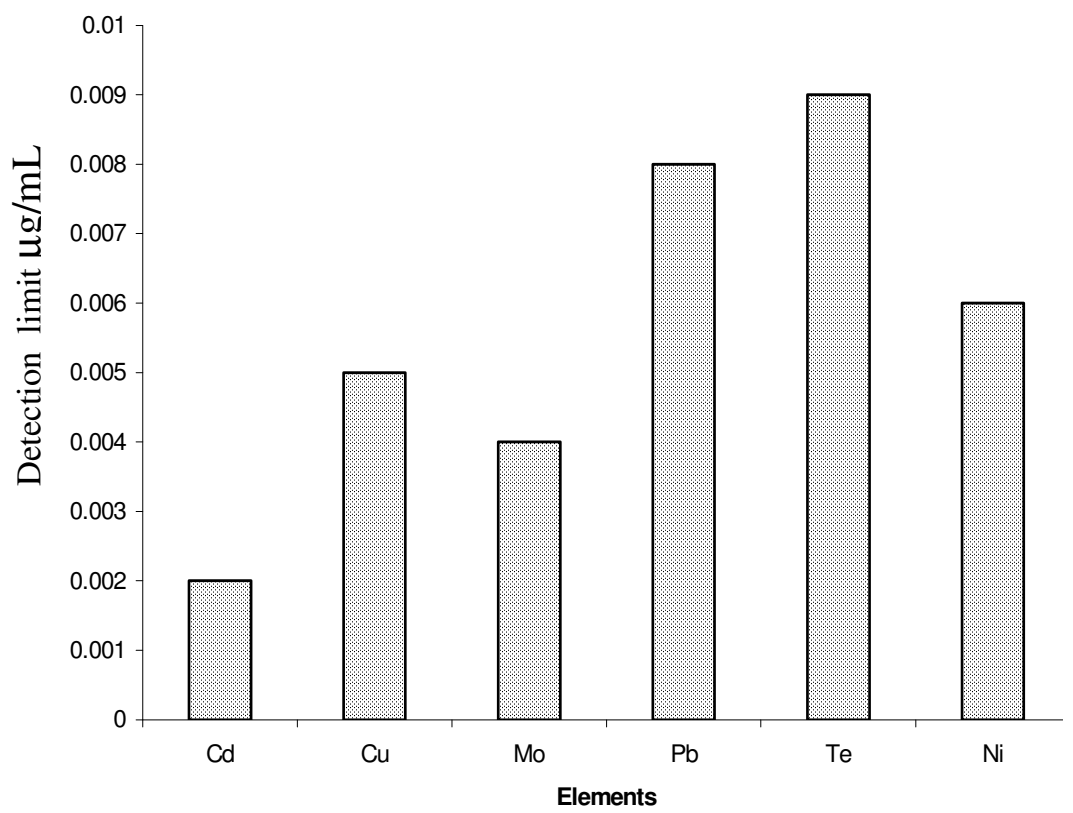

Figure 4. Detection limit for determination Trace Elements by AAS after preconcentration on polyurethane foam loaded with coniine dithiocarbamate.

\section{Conclusion}

The newly synthesised coniine dithiocarbamate loaded on polyurethane foam is selective method for determination of trace elements in low concentrations. The results presented in this paper have confirmed the applicability of the separation and preconcentration of metals.

This method is simple and there is no necessity for elaborate cleanup procedure, but the adsorbed metals are simply eluted with $5 \mathrm{~mol}^{-1} \mathrm{HNO}_{3}$ and were analysed by AAS.

\section{References}

1. Horrath Z, Lasztity A and Barnes R M, Spectrochim Acta Rev. 199114 (1/2) 45

2. Lo J M, Lin Y P and Lin K S Anal. Sci. 19917 (3) 455

3. $\mathrm{Xu} \mathrm{L} \mathrm{Q,} \mathrm{and} \mathrm{Schramel} \mathrm{P} \mathrm{Fresenius} \mathrm{J.} \mathrm{Anal.} \mathrm{Chem.} 1992342$ (1/2) 179

4 Zhang X, Satoh K., Satoh A, Sawada K and Suzuki T Anal. Sci. 199713 (6) 892

5. Reimes R A and Miyazaki A J. Anal At. Spectrum 19927 (8) 1238

6. Pai S Ch. Anal. Chem. Acta. 1998211 (1/2) 271

7. Prusisz B and Zyrnicki W Fresenius J. Anal. Chem. 1999363 (1) 110

8. Maccarthy P, Klusman R W, Cowling S W and Ricel J. A. Anal. Chem. 199163 (12) 301

9. Lichte F E, Hopper S and Osborn T W Anal. Chem. 198052 (1) 120

10. Olesik J W and Moore A W Jr. Anal. Chem. 199062 (8) 840

11. Rudner P C, Torres A G, Pavon J M C and Rojas F S Talanta 1998461095 


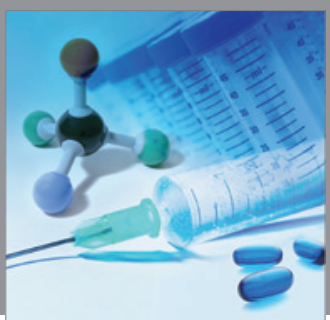

International Journal of

Medicinal Chemistry

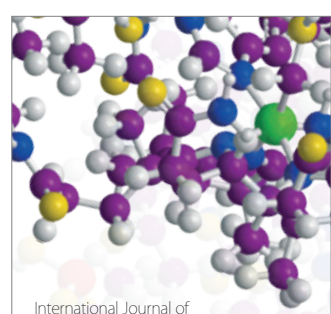

Carbohydrate Chemistry

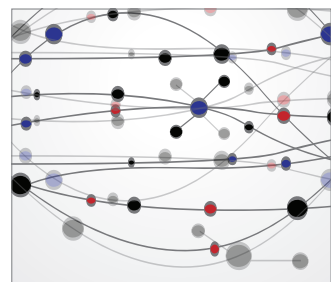

The Scientific World Journal
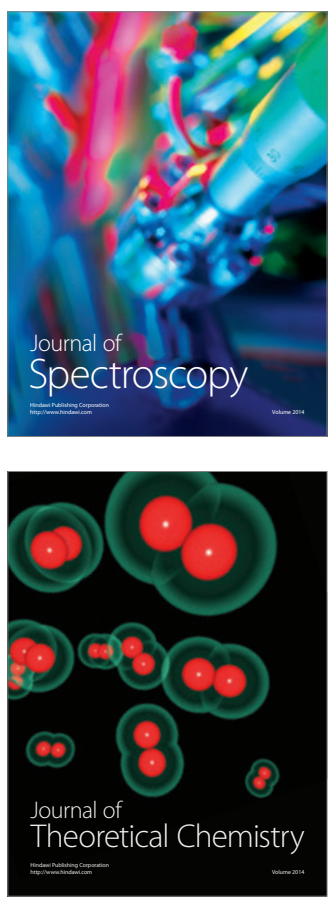
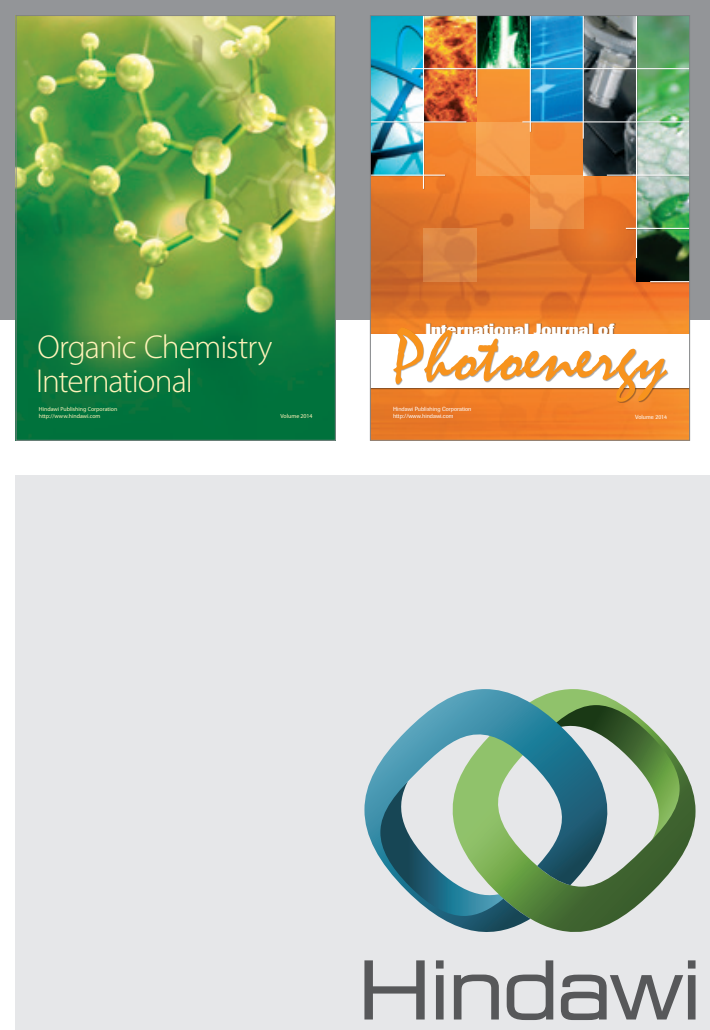

Submit your manuscripts at

http://www.hindawi.com
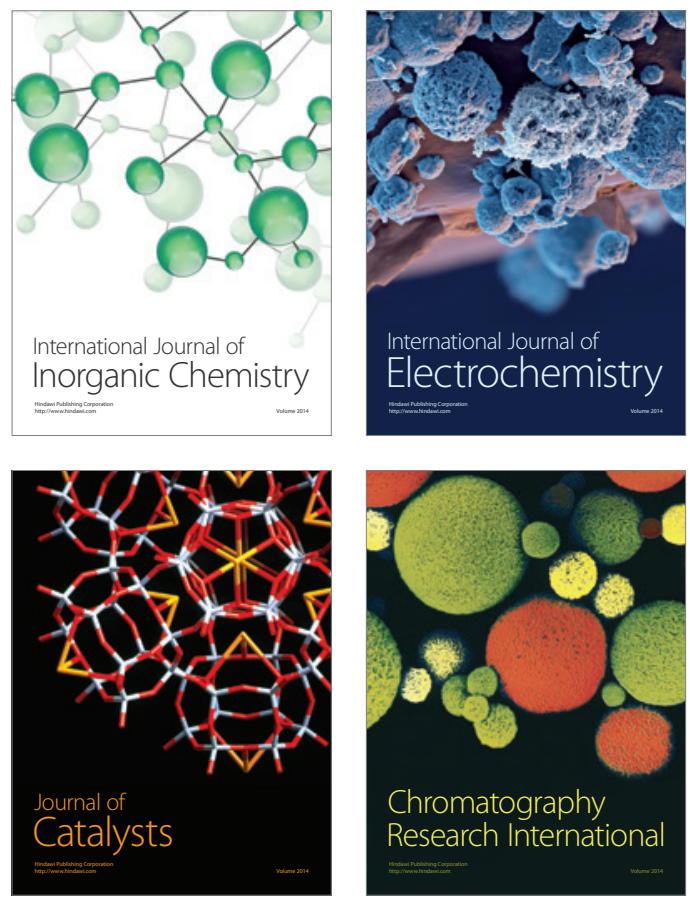
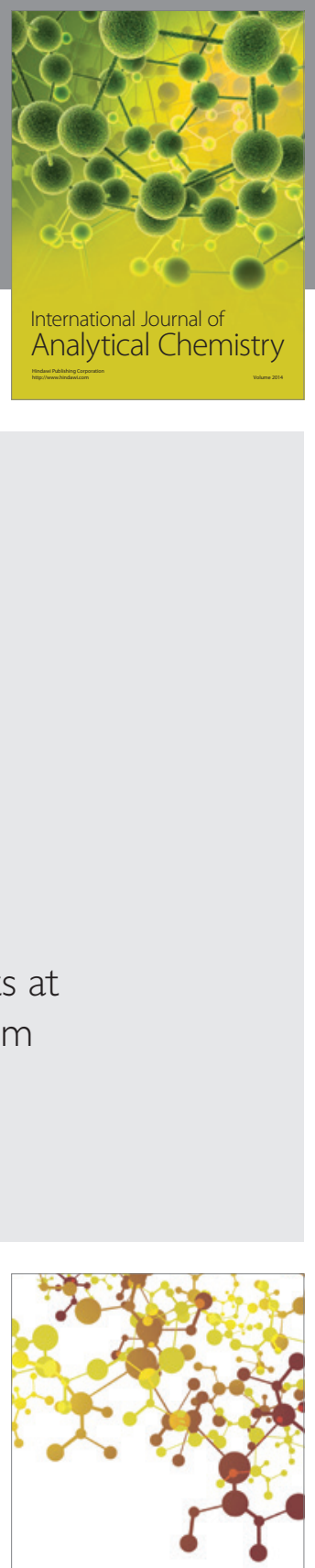

Journal of

Applied Chemistry
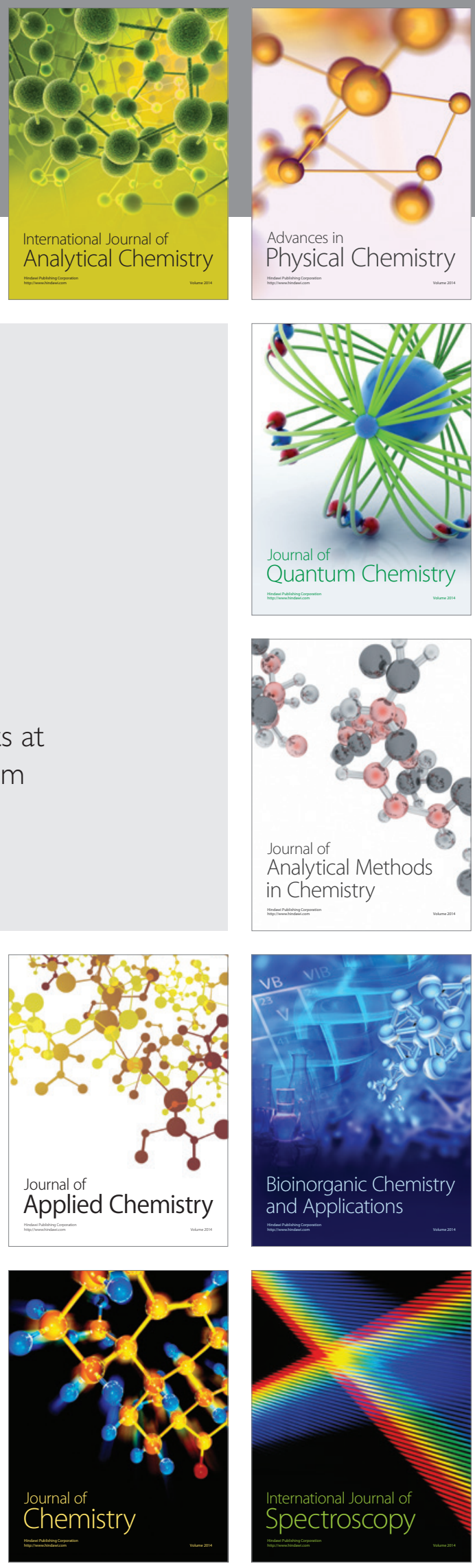